If herpes zoster and varicella are the same infection, it might be expected that an attack of the one disease would produce immunity against the other. A certain number of cases are recorded, and I have myself seen one few days ago, in which an adult, who had suffered from chicken-pox in childhood, developed herpes zoster, so that it must be admitted that an attack of varicella does not necessarily protect the individual against herpes zoster. I can find no record of a case of herpes zoster developing chiclien-pox later on, and in no case of herpes zoste associated with a generalized varicella-like eruption lias a previous attack of chicken-pox been recorded. That miglit mean that an attack of fierpes zoster protects the individual against chicken-pox, but individuals who have herpes zoster are in many cases past the age when they are likely to take chicken-pox.

Further knowledge on this question of inmurity is required. As both varicella and herpes zoster are seen more frequently by the general practitioner than by the dermatologist, much light might be thrown on the subject if practitioners made a point of inquiring in all cases of herpes zoster and chicken-pox as to previous attacks of either disease.

When discussing the cause of herpes zoster the cases which occur whilst arsenic is being taken inust not be jgnored. In such cases the question arises whether the arsenic produces an arsenical neuritis with the eruption in the distribution of the nerve or whether the arsenic makes the individual's nervous system more susceptible to infection with berpes zoster. The latter would seem to be tho more probable explanation, because even although the patient continues to take the arsenic, the herpes zoster runs a normal course, heals up, and does not recur, as one would expect, if an arsenical neuritis were the cause. Further, Parkes Weber ${ }^{25}$ relots an instance in which a patient was taking arsenic and developed herpes zoster with a generalized varicella-like eruption, and another patient from the same ward developed chicken-pox fifteen days later. Therefore $I \mathrm{am}$ inclined to consider arsenic like exposure to cold, worry, and so on, as merely a predis. posing cause to infection with the unknown virus.

[The first twenty-four references are to the Britis MEDICAL JOURNAL of the dates given

1 J. Hepworth, October 10th. 1918. 2 J. A. W. Pereira, May lst, 1915 $\therefore$ A. Z. C. Cressy, August 23rd, 1913. 4 J. D. Halstea'd. August $23 r a$ 19135 E. J. Bruce, August 30th, 1913. 6 G. E. Roberts, August 30th 1913. 7 E. Harrisqn, August 30th, 1913 H. Oakes, Angust 30th, 191 W. H. Coates, August 30th, 1913. $10 \mathrm{H}$. S. Wilson, Auqust 30th, 1913 11 A. Savill, October 4th, $1913.12 \mathrm{~J}$. A. Milne, October 4th, 1913 Dando, November 15th, 1913. 16. J. H. Bartlett, November i5th, 1913 17 B. Jones, May 21th, 1913 . 18 G. C. Walker, May 31st, 1913 . 19 Parkes Weber, February $15 t$ th. 1913. 20 Ffrench, 1899, vol. i, p. 388. 2i Le Feuvre.
1915, vol. i, p. 15. 22 Distin, 1915, vol. i, p. 633. 23 H. Taylor, 1889, vol. ii. p. 13. 24 S. Flexner, 1912, vol. ii, p. 1261. 25 Parkes Weber, Initernat. Clinics, 19i6, vol. iit. Series 26.' 26 Pernet, Brit. Journ. Dermatol. October, 1914, p. 399. 27 Dopter, Presse médicule, 1910, p. 162.28 P. Heim, Berl. Klin. Woch., December 9th, 1912, p. 2349. 29 Arkwright St. Bartholomew's Hosp. Journal, 1900, vol. vii, p. 172. ${ }^{30}$ Jeanselme an Leredde. Bull. Soc. méd. des Hôp. de Paris, 1893, vol. xv, p. 619 Archiv $f$ Werm. Kln. Woch. September 30th. 1909. 32 R. Beye Archiv f. Derm. u. syph.. 1906, vol.78, p. 233 . S. H. Fasal, ibid., 1909, vol. 95, p. 27. S4 Le Fenvre, Med. Jmu'n, of S. Africa, 19l1, vol. ix Med. Assoc., 1910, vol. 54, p.532. 37 Nobl, Wien. klin. Woch., 1911, p. 17 $8 \times$ Barber, Guy's Hosp. Gazette, September 23rd. 1916. 99. J. N. Watso ibid., April 24th, 1915. 40 F. J. Coleman, ibid.. May 10th. 1913. ${ }^{41} \mathrm{R}$. S Wain wright, ibid., May 10th, 1913. 42 F. Hea therley, ibid., April 25th, 1914. 43 F. Fischl, Archiv f. Derm. u. Syph . 1913, p. 553. 44 Jeanselme and Touraine, Soc. franc de derm. et de syph. July 2nd, 1914 F. Steuer, Wien. klin. WGch., 1911, p. 1167 , Minet and Leclerca. La i9 Tryb, Dermat. Wochenschr., 1914, p. 983.

\section{PUBLIC MEASURES FOR THE PREVENTION OF 'TUBERCULOSIS.}

BY

Lieut.-Colonel NATHAN RAW, C.M.G., M.P., M D., o.C. And Sensor Physician, Liverpool Hospital. France.

Tue spread of tuberculosis in any community can only be checked by public measures forming a co-ordinated scheme for attack on the disease. 'Tuberculosis being to a large extent a disease of ignorance and misery, our efforts to prevent it must be directed towards the social conditions and insanitary surroundings of the poor. It is essential to establish very close co-operation between voluntary action and Government and municipal efforts.
The general measures for the control of tuberculosis may be stated under the following heads:

Voluntary and Compulsory Notification.

Tuberculosis being essentially an infectious disease it is desirable that complete notification of all cases should be made to the officials who are responsible for the public health, so that they may be informed as accurately as possible as to every person infected with the disease.

In England voluntary notification has been superseded by: compulsory notification, at least as far as pulmonary tuberculosis is concerned, and although it is open to question whether it is desirable to notify the private patients of aedical mun; yet if a certain amount of dis cretion is exercised there can be no doubt that compulsory. notification is in the general interest of the community, although it may press hardly, on individuats. An order from the Local Government Board for England and Wales compels the notification of erery inmate of a public institution suffering from any form of tuberculosis. 'This notification numst be made on special forms by the physician attending the case; for this he receives the small fee of $1 \mathrm{~s}$. As soon as notitication is received by the health officer a visit is paid to the home of the patient, and a careful inquiry as to his personal condition and surroundings made. If, in the opinion of the health officer, his home surroundings, are such as to make it unsafe for him to remain, power is given to remove the patient to some institution, but this power is very rarely exercised.

In large cities where a great amount of overcrowding exists, the treatment of the adranced case of tuberculosis is of supreme importance. If he is allowed to live in the same $d$ welling and share the same room as his wife and clillren, it will almost certainly happen th, $t$ one or all of his family will become infected. 'T'herefore it is absolutely necessary that he should be removed to some safer surroundings unless he is able to have a room to himself and to look after his own personal cleanliness. It is no use to keep a patient in a sanatorium for six months and then discharge him as incurable, to spend the rest of his life in an' overcrowded cottage or tenement where he may spread the infection to a new generation. Provision ought to be made, either: by. Government or by the municipality, for the detention and comfortable treatment of all cases of incurable tuberculosis $\mathrm{L}$ am not in favour of exercising compulsory powers of removal from a mans own home, but if it is for the protection of healthy people, then re. moval ought to be made compulsory; but 1 think it will be some time before public opinion is ripe for such measures.

'The tiealth: authority will disinfect and clean the clothing and bedding of any notified case, and then will also carefully disinfect the house in which he has lived. Very often the patients complain of this attention to their homes and their clothing, but it: is essential that it should be done for the protection of the future residents of the house. It is atso the practice to notify to the health athorities any change of address of a tuberculous person, so that they maxy keep in touch with any house in which he may live.

On the whole, compulsory notification will prove useful in the fight agaiust the disease, but it should only be used in a wise and gentle manner, as otherwise it is liable to cause personal discomfort, and may have the effect of ostracizing the patient from society. If it is pushed too far. it may also have the effect of preveuting him from earning his livelihood by reason of his fellow-workers having a fear : of infection in the workshop or factory. Although many countries are still doubtful as to the wisdom of euforeing compulsory notification, yet from the point of view of suppression of an infectious disease it cannot be denied that with care and consideration the compuisory notification of tuberculosis is bound to do good.

Removal of Affected Children from School and Home. The medical inspection of school children is now thorough and complete in Great: Britain, as in many other countries, with the result that a fair number of children of school age are recognized as suffering from pulmonary tuberculosis, although this number is not so large as one might be inclined to expect. Pulmonary tuberculosis is comparatively: uncommon amongst school children; the other forms of tuberculosis are more often seen. A child suffering from apen tuberculosis should at once be removed from school, mainly for the protection of the other 
children, as it is possible for one child in an overcrowded and badly ventilated schoolroom to infect several of its fellows. - In a family the infected child should, if possible, always be provided with separate accommodation; or, better still, removed from the family circle until recovery has taken place; on no account should the child sleep with any other children, or even with its parents.

\section{Treatment of Children in Special Children's} Sanatoriums.

The provision of special sanatoriums for children is, I am glad to say, in England making steady and rapid progress; many of these sanatoriums have been provided by the education authorities, with excellent results. It has been found undesirable for children to be treated in a sanatorium for adults; hence it is necessary to provide special institutions for them. The children's sanatorium has the double advantage of continuing the education of the clild and at the same time providing the means of cure of the disease. In countries where the climate is more suitable for this treatment a gieat many such sanatoriums have been provided, and in Great Britain much success has attended their adoption.

\section{Education of the General Public with Regard} to the Disease.

The main point in the campaign against tuberculosis must be the education of the general public with regard to the disease. The National Association for the Prevention of Consumption aims almost entirely at this part of the work; it has numerous branches in most of the large cities and towns of the British Isles, where the work of education of the public is steadily pressed forward. A travelling exhibition, provided with models of everything necessary in the treatment of the disease, is constantly moving from place to place; demonstrations are given by competent teachers on the management and nursing of children and the prevention of tuberculosis, and popular lectures are given each evening by experts. In this way an enormous amount of information is steadily disseminated. Education of school children is constantly going on, and the teachers themselves are instructed in the nethods of prevention and treatment of tuberculosis. Literature is scattered broadcast throughout the land, and illustrated posters are affixed in every town, so that all possible means are used to convey to the public the information 'so' much required.

\section{Provison of Municipal. Dispensaries in Every} Commanity.

The public dispensary has been proved to be of value in the treatment of poor persons afflicted with tuberculosis, and it is suggested that in every town the health authority should provide municipal dispensaries where the poor may receive attention and where the most careful inquiry can be made with regard to their families. The house of every infected person is carefully inspected and the acconmodation noted. Advice as to nursing, isolation, and treatment is given in every case, and, where necessary, rigorous action is taken by the health inspectors. In this way it is hoped that every affeeted person may have the opportunity of receiving advice and treatment, together with assistance to his family if necessary.

In the case of insured persons transferred to a sanatorium under the National Insurance Act, dependants of the family will receive $10 \mathrm{~s}$. a week for six months, and, if necessary, further assistance will be given to the affected person. 'This is a great step in advance, and will undoubtedly induce a great many of the working class to accept treatment in a sanatorium, knowing that their family will be provided for in the meantime.

\section{Provision of Sanatoriums for the Cure of} Early Cases.

The provision of sanatoriums for treatment and cure is a vital necessity. 'Tuber'culosis in its early stages responds admirably to sanatorium treatment, and it must be our aim in the future to obtain the cases at the earliest possible moment, so that they receive special treatment with a view to cure, and also receive special education and instruction with regard to their manner of living in the future. The sanatorium itself should be reserved for early casses of -bubereulowis; it comnat be expeeted to do much good in advazeed cases, and being of a very costly character its resources should be reserved for hopeful and curable patients. In the national insurance scheme such sana toriums will be erected in every locality, and every suitabte case will have opportunity of cure. The results of sanatorium treatment have been excellent, and it is hoped that they will be still further improved as a better selection of patients is made.

\section{Institutions for Advanced Cases.}

In my opinion the most potent factor in the spread of tuberculosis is the advanced case who is not under proper supervision. The man in the final stages of consumption, who is pouring out millions of bacilli from his lungs each day and who has not physical: strength to look after himself or take ordinary care, is a serious danger to the community. These are the people who require the most rigorous supervision and who as a rule are neglected by everybody. The late Professor Koch often said that he attributed the steady decrease in tuberculosis in England to the fact that such a large number of advanced cases of tuberculosis were isolated and treated in the Poor La. institutions of Great Britain. This opinion is undoubtedly true; the very fact that so many were constantly segregated must have had a great intluence in the decline of consumption. Special institutions should be provided for advanced cases where they may be made comfortable and happy to the end, but it is doubtful if it would be wise at present to enforce isolation of such cases, although I have no doubt that in the future this will have to be done.

\section{Hcme Training and Supervision amongst the Working} Classes.

Tuberculosis being a disease of long standing, those who suffer from it should be instructed in the manner of living at home. The working man or working woman must attend to daily duties, in many cases for years, whilst suffering from the disease; hence the sufferer, if he is to live at home with safety, must know how to protect the other member's of the family. There is a strong prejudice in England against the working man using a sputum flask in the workshop or factory, so that there is every temptation to conceal the disease. It is not desirable, however, that a workman should be treated as a leper because he happens to be infected with tuberculosis, otherwise be is in danger of losing lis ordinary place in the labour world, and becoming a burden on the community. It is much more necessary that he should be instructed how to take care of his expectoration, and how to prevent the slightest tendency of infection to the healthy members of the community; if this is done there is no reason whatever why he should not attend to his daily work and associate in ordinary social life. There is a great danger of frightening consumptives, and our efforts must be towards removing that fear, and educating the general public in the right direction.

\section{Rigoraus Superyision of the Milk Supply.}

The question of a pure milk supply is of the tirst impor. tance in every community; and of urgent importance, as it is the staple food of infants and children. Notwithstanding what has been said by nany'experts in different countries, there can be no doubt that a large amount of tuberculosis is conveyed to children by infected milk and food. Tuberculosis is very common amongst dairy cows in Great Britain and Ireland-in fact, about 20 per cent. of cattle are infected with the disease at the present time. Cows with tuberculosis of the udder are, however, by far the most dangerous, and hence only about 2 per cent. of the infected cows are highly dangerous to children. It is the practice, however, in this country to mix all the millk from a herd of cows, so that one cow with disease of the udder may contaminate the whole milk supply. Whilst consumption is steadily decreasing in this country, the same cannot be said for tuberculosis in children. A very large number of the lesions occurring in children are the result of infection from tuberculous animals in the form of foor, and every step must be taken to prevent such contamination.

Legislation has recently been introduced in England with a view of establishing a pure mill supply; it is proposed that all persons offering milk for sale should be registered and their premises periodically inspected. Every cow supplying milk will be under rigorous inspection 
by the health authorities, and compensation will be paid to the owner of any cow which is found to be suffering from tuberculosis. In the meantime the public are advised to sterilize the milk before being given to infants, with a view to destroying tubercle bacilli and other organisms. In Liverpool a great amount of special care has been taken by the health authority to safeguard the milk supply. Special powers have been obtained to inspect the source of all milk coming into the city, and the result has been that I have myself observed a steady decrease in liospital of children suffering from tuberculosis.

The amount of disease conveyed from animals to man seems to vary in different countries. In Scotlund there is more than in England; whilst in the British Isles there appears to be more tuberculosis conveyed by milk than on the Continent, where it is almost the universal practice to pasteurize the milk before drinking. Whether this be so or not, we are all agreed that in the campaign agaiust tuberculosis every effort must be made to eradicate the disease from dairy cows. This, I admit, is a very costly undertaking, and millions of pounds would be required to do it effectively in England alone. The sclieme suggested by Bang has had excellent results in Copenhagen, and a similar process should be gradually introduced into every country.

\section{Assistance to Family in the Absence of the}

$$
\text { Bread-uinner. }
$$

The question of providing assistance to the family in the absence of the bread-winner during his stay in a sanatorium has been to a great extent solved by the provision in the National Insurance Act already referred to, but this work requires further extension, and a central fund ought to be provided in every community for the special purpose of looking after the family when the parent is undergoing cure; otherwise it is impossible to expect him to give himself up to treatment for any prolonged time.

\section{Provision of Suitable Employment in Cured and Arrested Cases.}

The question of providing suitable employment for cured cases, and for those in whom disease is arrested, is one of great difficulty, although of inmense importance. Very many private employer's are now giving such workers ont. of door, easy employment, as it is only in this way that they can be expected to remain well and fight the battle of life. We wish to extend this practice, and appeal confidently to those employers of labour who have the opportunity of making such provision for their workers.

By adopting a combination of measures sucl as those enumerated, we can confidently hope slowly but surely to exterminate the disease which ought not to be in our midst, but is provoking such an amount of havoc, misery, and loss of haman life. The new Ministry of Health, by co-ordinating and controlling all the necessary measures for the prevention and control of tuberculosis will be the means of saving an enormous amount of suffering and vastage of valuable human lives.:

\section{An 3ntrostigation}

INTo

\section{THE INCIDENCE OF ALBUMINURIA AND CASTS IN BRITISH SOLDIERS DURING TRAINING,}

\section{AND TIIE RELATIONSHIP OF THIS CONDITION} TO WAR NEPHRITIS. *

By H. MaCleaN, M.D., D.Sc., Captain R.A.M.C., IECTURER ON CHEMICAL PATHOLOGY, ST. THOMAS'S hospital.

The question of the incidence and significance of albu minuria in the soldier has in the past received very little attention, and the literature contains but scanty informa tion as to the extent to which kidney deficiency is present in the army. Whough the recruit is supposed to be physically fit, little provision is made for the testing of $\cdot$ his renal function at the time of his medical examination, witl

* Summary of a report to the Committee on War Nephritis of an investigation carried out under the unspices of the Medical Research Committee. the result that the milder cases of nepliritis without objective symptoms are likely to be drafted into the army. The outbreak of acute nephritis (so-called war nephritis) which began at an early stage of the war and still continues, rendered it necessary to investigate more fully the incidence of albuminuria and possible kidney lesions in the fighting forces, and it was in this connexion that the present investigation was carried out

The original idea was to examine the urines of large numbers of men before they took part in active operations, and later on to correlate the information gained with the official returns of nephritis obtained from these men. It would thus be ascertrined whether or not the majority of the cases ultimately retarned as suffering from war. nephritis had albuminuria at an earlier period. Such an investigation, though difficult and laborious, was obviously essential if any real light was to be thrown on the etiology of war nephritis, for in each case of nephritis that appeared one was always confronted with the unanswer. able question: Has he lad some kidney defect previously, and is this merely an exacerbation brought on as the result of the conditions of warfare, or has it arisen de nuvo? In the majority of cases an answer to this question could not be furnished by any clinical observations made on the patient while actually suffering from the disease, for the problem of pre-existent renal trouble is a most difficult one, and in many cases incapable of solution. It is perliaps not sufficiently recognized that renal disease may be present with few or no clinical symptoms, though evidence can often be obtained by careful laboratory investigation. On the other hand, it is now acknowledged that an acute attack may in a short time result in certain cardiac and other changes strongly suggestive of chronic disease.

If, however, it were found that the great majority of war nephritis cases were suffering from albuminuria when examined at an earlier stage, then one might say with con. fidence that war nephritis was probably dependent on a pre-existing kidney lesion, which, though perhaps originally slight in degree, yet gave rise to an acute inflammatory process as the result of the necessary exposure and fatigue of the campaign.

The question of the possible relationship of albuminuria to war nephritis was, however, only one of the many points on which it was hoped to obtain. much-needed infornation. Various problems, such as the effect of training, the part played by previous diseases, the influence of age and other factors on albuminuria, were in restigated.

In all, 60,000 men were examined. Of these, the first 50.000 were men who had finished their course of training in li gland and had come to a base in France for a short period-generally nine or ten days-to complete their. training before going to the front. Some of these, of course, had been in the line before, and were returning after being wounded or sick, but these constituted only an insignificant proportion of the total. The last 10,000 men were examined at Aldershot, and chiefly represented recruits who had undergone little or no training. They gave practically similar results to the other 50,000 .

\section{General Procedure in Examination and Collection of Urine.}

In any investigation of albuminuria it is necessary to ensure the collection of specimens under suitable and conparable conditions. The incidence of albuninuria in $a$ group of soldiers is often increased by as much as 100 per. cent. or more as the result of a few hours' active exercise, so that a series of samples taken from the same men in the morning and at night would show very marked differences. Specimens should always be taken in the morning, since in this case the results are comparable, and really indicate the minimum incidence of albuminuria in any group of men at a given time. All the urines examined were, therefore, taken early in the morning, and, where possible, consisted of the first specimen passed. Various special arrangements, which need not be detailed hore, were neccassary to obtain particulars of the men for future identitication.

Tests used for Protein and Methods of Grading Trines acrording to Amount of Albumin.

The testing reagent used in this investigation was salicyl. sulphonic acid. Of all the protein tests this is maloubtedly oue of the most reliabie and delicate; it is so easily applied that 